\title{
DUT som didaktisk felt - en empirisk analyse af didaktiske temaer i perioden 2006-2013
}

Tina Bering Keiding, lektor, Center for Undervisningsudvikling og Digitale Medier, Aarhus Universitet

Ane Qvortrup, lektor, Institut for Kulturvidenskaber, Syddansk Universitet

\section{Reviewet artikel}

Artiklen foretager en systematisk kategorisering og analyse af de bidrag, som har været bragt i Dansk Universitetspædagogisk Tidsskrift (DUT) fra 2006-2013. Formålet er at undersøge, hvilke didaktiske temaer tidsskriftet har været optaget af og at diskutere mulige implikationer for universitetspædagogikkens funktion i forhold til at bidrage til undervisernes didaktiske viden. Analysen viser, at bidragene altovervejende er optaget af metodespørgsmål, og inden for denne kategori stort set udelukkende har beskæftiget sig med handlingsorienterede og/eller dialogiske undervisningsformer.

\section{Universitetspædagogik og -didaktik}

Kravet om pædagogisk professionalisering af folkeskolelærere kan spores tilbage til anden halvdel af det 18. århundrede (Luhmann, 2006). Derimod ser vi først en tydelig interesse for universitetsundervisernes pædagogiske faglighed i midten af 1980'erne. Interessen medførte for det første et fokus på systematisk udvikling af underviserkompetencer. For det andet resulterede den i opblomstringen af et nyt forskningsområde, som fik betegnelsen "Scholarship of Teaching and Learning" (SoTL) (Murray, 2008; Trigwell, Martin, Benjamin \& Prosser, 2000).

I 1999 udgav Fry, Ketteridge og Marshall (1999) A Handbook for Teaching and Learning in Higher Education. Bogens undertitel - Improving Academic Practice - indfanger et fælles mål for den universitetspædagogiske forskning (fx Biggs \& Tang, 2011; Tight, 2008a).

Da Dansk Universitetspædagogisk Tidsskrift (DUT) udkom for første gang i 2006, blev det helt i tråd med den internationale tendens tydeligt rammesat som et forsøg på at skabe et nationalt forum for praksisrelevant forskning i relation til de videregående uddannelsers pædagogik:

"Målet er, at Dansk Universitetspædagogisk Tidsskrift kan blive forum for udveksling af universitetspædagogisk forskning, information, refleksion, kritik og inspiration og for udveksling af universitetspædagogiske erfaringer og holdninger. Det er målet, at denne udveksling både vil ske mellem undervise- 
re indbyrdes og mellem undervisere og ledere, så tidsskriftet kan bidrage til en bred, skriftlig, tværinstitutionel universitetspædagogisk offentlighed i Danmark." (Jensen, 2006).

$\mathrm{Nu}$ - næsten ti år efter udgivelsen af første nummer - vil vi i denne artikel se nærmere på DUT som platform for formidling af dansk universitetspædagogisk forskning med særligt fokus på didaktiske temaer.

Forskningsspørgsmålet er: "Hvilke didaktiske temaer adresserer tidsskriftet og hvilket fokus tilbyder det hermed for analyse og refleksion over universitetsundervisning?"

Artiklen kan ses som en didaktisk metaanalyse i den forstand, at den analyserer hvilke temaer, de didaktiske analyser beskæftiger sig med og dermed tegner et overordnet billede af hvilke didaktiske problemstiller, der formidles via DUT.

I international sammenhæng finder vi andre eksempler på metaanalyser af universitetspædagogiske tidsskrifter. Tight (2004) undersøger eksempelvis det teoretiske grundlag i 406 artikler fordelt på 17 tidsskrifter specialiseret mod de videregående uddannelsers pædagogik. Undersøgelsen viser, at det teoretiske perspektiv i flertallet af artiklerne enten er implicit eller helt fraværende. I forlængelse heraf rejser Tight spørgsmålet om, hvorvidt forskningen i videregående uddannelse bedst beskrives som et a-teoretisk praksisfællesskab. I Tight (2007) foretages en analyse af de samme artikler i forhold til temaer, analytisk enhed (individ, fag, afdeling etc.) samt forskningsmetode. Af særlig relevans for nærværende artikel er, at Tights metaanalyse peger på, at undervisningsdesign er et hyppigt forekommende tema, især i ikkenordamerikanske tidsskrifter. Denne artikels fokus ligger også på undervisningsdesign. I forhold til Tight (2007) går den dog yderligere ned i detaljeringsniveau og spørger til, hvilke didaktiske kategorier forskningen beskæftiger sig med.

\section{Analysestrategi}

Analysestrategien består dels af en teoretisk ramme, der leverer de analytiske kategorier, dels af et empirisk design.

\section{Teoretisk ramme}

Didaktikken kan ses som den deldisciplin af pædagogikken, som beskæftiger sig med opdragelsens og undervisningens mål, indhold og metode (Broström \& Hansen, 2006). Den teoretiske ramme hentes i den læreteoretiske didaktik (Heimann, 1976; Keiding, 2013a). Den læreteoretiske didaktiks hovedambition var at udvikle en praktisk anvendelig didaktisk teori, som anlagde et didaktisk helhedssyn på undervisningen. Det er netop det tilstræbte helhedsblik, som gør den læreteoretiske didaktik velegnet som analytisk udgangspunkt for konstruktion af didaktiske opmærksomhedspunkter, fordi dette skaber et systematisk afsæt for at tydeliggøre både hvilke didaktiske temaer, der adresseres i artiklerne, og hvilke der ikke adresseres. 
I den læreteoretiske didaktik skelnes mellem to former for analyse: strukturanalyse og faktoranalyse (Heimann, 1976; Keiding, 2013). Strukturanalysen orienterer sig mod didaktiske valg ift. kategorierne 'intention', 'indhold', 'metoder', 'medier', 'deltagere' og 'organisatoriske rammer'. De didaktiske kategorier i den læreteoretiske didaktiks strukturanalyse ses i figur 1 .

\begin{tabular}{|c|c|c|}
\hline Undervisning som fænomen & $\begin{array}{l}\text { Didaktisk } \\
\text { spørgsmål }\end{array}$ & $\begin{array}{l}\text { Teoriens didaktiske kate- } \\
\text { gorier }\end{array}$ \\
\hline \multirow{3}{*}{$\begin{array}{l}\text { "Der er én som har en bestemt hensigt. } \\
\text { I den hensigt bringer han en genstand } \\
\text { ind i en bestemt gruppe menneskers } \\
\text { horisont. }\end{array}$} & $\begin{array}{l}\text { Med hvilken hen- } \\
\text { sigt gør jeg dette? }\end{array}$ & $\begin{array}{l}\text { Intention (formål, mål, } \\
\text { hensigt) }\end{array}$ \\
\hline & $\begin{array}{l}\text { Hvad bringer jeg } \\
\text { ind i børnenes } \\
\text { horisont? }\end{array}$ & Indhold \\
\hline & $\begin{array}{l}\text { Hvordan gør jeg } \\
\text { det? }\end{array}$ & Metoder \\
\hline $\begin{array}{l}\text { Han gør det på en ganske særlig måde } \\
\text { og under anvendelse af ganske bestem- } \\
\text { te hjælpemidler, som vi betegner 'medi- } \\
\text { er'. }\end{array}$ & $\begin{array}{l}\text { Med hvilke medi- } \\
\text { er virkeliggør jeg } \\
\text { dette? }\end{array}$ & Medier \\
\hline \multirow[t]{2}{*}{$\begin{array}{l}\text { Og han gør det også i en ganske be- } \\
\text { stemt situation" (Heimann, 1976, s. 105). }\end{array}$} & $\begin{array}{l}\text { Til hvem formid- } \\
\text { ler jeg dette? }\end{array}$ & $\begin{array}{l}\text { Elevernes læringsforud- } \\
\text { sætninger }\end{array}$ \\
\hline & $\begin{array}{l}\text { I hvilken situation } \\
\text { formidler jeg det- } \\
\text { te? }\end{array}$ & Rammer \\
\hline
\end{tabular}

Figur 1. De didaktiske kategorier i den læreteoretiske didaktiks strukturanalyse. Her efter Keiding (2013).

I strukturmodellen optræder eksamen ikke som en særskilt didaktisk kategori. Set i lyset af, at den empiriske uddannelsesforskning har påvist, at eksaminernes indhold og form har afgørende betydning for de studerendes læringsstrategi, tilføjes eksamen som en selvstændig analytisk kategori (Biggs \& Tang, 2011:169; Ramsden, 1992:187).

Faktoranalysen retter blikket mod de præmisser, normer og værdier, der konditionerer de didaktiske valg, der træffes i strukturanalysen. De to didaktiske analyser og deres fokuspunkter er illustreret i figur 2 . 


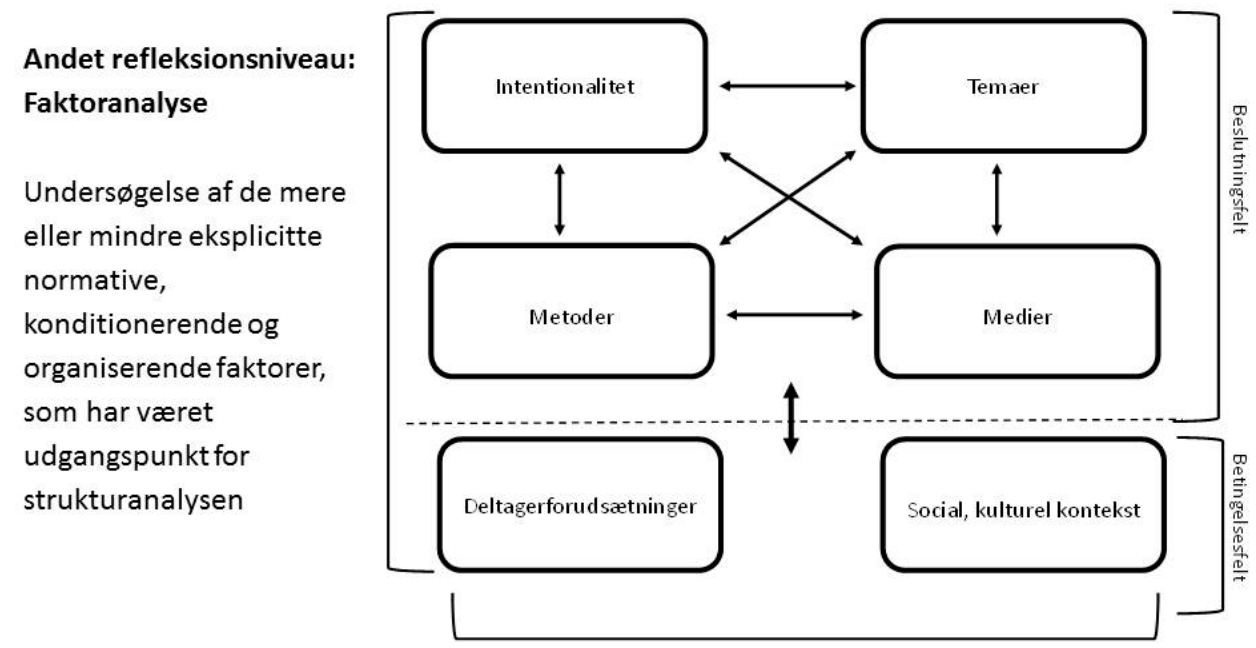

Første refleksionsniveau: Strukturanalyse.

Beslutning om og refleksion over interdependens mellem de 6 grundelementer

Figur 2. De to didaktiske refleksionsniveauer, som indgår i den læreteoretiske didaktik. Dels strukturmodellen og dennes seks analytiske kategorier, dels faktoranalysen og de spørgsmål som knytter sig hertil. (Efter Keiding, 2013).

\section{Empirisk design}

Analysen af de didaktiske temaer i DUT sker på baggrund af en kategorisering af samtlige artikler i DUT fra nr. 1 (2006) til og med nr.15 (2013). I kategoriseringen anvendes de seks kategorier i den læreteoretiske didaktiks strukturanalyse ('hensigt', 'indhold', 'metode', 'medier', 'studerende' og 'rammer') samt kategorierne 'eksamen' og 'faktoranalyse'. Betingelserne for indikation er knyttet til artiklens primære didaktiske fokus. Figur 3 viser et eksempel på, hvorledes de analytiske kategorier er operationaliseret. 


\section{Forste niveau for didaktisk analyse: Strukturanalyse}

\begin{tabular}{|c|c|}
\hline Hensigt & $\begin{array}{l}\text { "Artiklen analyserer læringsmålene for det almene gymnasium og } \\
\text { kursusbeskrivelser for to universiteter med fokus på progression } \\
\text { og vidensformer" (Dahl, 2010). }\end{array}$ \\
\hline Indhold & $\begin{array}{l}\text { "Med udgangspunk i kategorier primært genereret fra almendidak- } \\
\text { tikken beskrives og diskuteres } 116 \text { underviseres begrundelser for } \\
\text { valg af indhold" (Keiding \& Hansen, 2012). }\end{array}$ \\
\hline Medier & $\begin{array}{l}\text { "På baggrund af en sociokulturel tilgang til begrebet personlige } \\
\text { læringsmiljøer sætter artiklen fokus på, hvordan internettet kan } \\
\text { understøtte universitetsstuderendes aktiviteter" (Dalsgaard, 2011). }\end{array}$ \\
\hline $\begin{array}{l}\text { Metode, inkl. } \\
\text { vejledning }\end{array}$ & $\begin{array}{l}\text { "Artiklen beskriver og analyserer et undervisningseksperiment ved } \\
\text { RUC, som udvider og udvikler projektpædagogikken" (Dupont, } \\
\text { 2012). }\end{array}$ \\
\hline Eksamen & $\begin{array}{l}\text { "I denne artikel vil vi diskutere, hvordan studerendes arbejde med } \\
\text { udformning af en videnskabelig artike/ som afsæt for summativ } \\
\text { evaluering af undervisningsmoduler" (Stentoft \& Østergaard, } \\
\text { 2013). }\end{array}$ \\
\hline Studerende & $\begin{array}{l}\text { "I denne artikel vil jeg, på baggrund af et igangværende ph.d.- } \\
\text { projekt, søge at nuancere billedet af nutidens unge universitets- } \\
\text { studerende" (Thomsen, 2007). }\end{array}$ \\
\hline Rammefaktorer & $\begin{array}{l}\text { "[Artiklen undersøger] aspekter af en strukture/ adskillelse af måls- } \\
\text { tyrede og projektbaserede undervisningspraksisser med arkitekt- } \\
\text { uddannelsen" (Grønbæk \& Hedegaard Møller, 2013). }\end{array}$ \\
\hline
\end{tabular}

\section{Andet niveau for didaktisk analyse: Faktoranalyse}

Spørger til be- "Målet med artiklen er teoretisk at påvise, at anvendelsen af Biggs' greber og vær- constructive alignment (CA) (1999) samt af Biggs og Collis' SOLOdier taksonomisom grundlag for udvikling af uddannelser og undervisning i dansk universitetspædagogik medfører en risiko for generalisering og simplificering" (Leth Andersen, 2010).

Figur 3. Eksempler på operationalisering af analytiske kategorier, som de fremstår i teksterne.

Kategorisering sker på baggrund af artiklens abstrakt. Selve artikelteksten inddrages kun i analysen, hvis det didaktiske tema ikke fremgår klart af abstraktet.

Seks artikler falder uden for de foruddefinerede didaktiske kategorier: Disse omhandler primært underviserrelaterede problemstillinger, blandt andet kompetenceudvikling og kollegial supervision. I alt indgår der 115 artikler i analysen. Bidrag, der adresserer mere end én didaktisk kategori, tælles med i hver af de relevante kategorier. Således overstiger summen af markeringer i de to analyser det samlede antal artikler. 
Begge forfattere deltog i kategoriseringen. Proceduren var, at vi delte de 15 numre mellem os og individuelt foretog den første kategorisering. Efterfølgende blev kategoriseringerne samlet $\mathrm{i}$ et dokument og drøftet med henblik på at kontrollere individuelle kategoriseringer. Dette bidrog dels til at sikre ensartethed i kategorisering, dels til løbende refleksion over operationaliseringen af de didaktiske kategorier.

Kategoriseringen viste, at flertallet af bidragene faldt inden for metodekategorien. For at få et systematik indblik i hvilke undervisningsmetoder, der blev adresseret, besluttede vi at foretage en yderlig kategorisering af de metodeorienterede bidrag. Som analytisk systematik anvendte vi den didaktiske trekant, som beskriver tre didaktiske hovedpositioner: Underviser-indholdsorienteret undervisning; Underviserstudent/Student-student-orienteret undervisning eller Student-indholdsorienteret undervisning (Künzli, 1998).

Relevansen af et særligt fokus på de beskrevne undervisningsmetoder henter sin begrundelse i den empirisk baserede uddannelsesforskning, som peger på, at metodemangfoldighed har afgørende betydning for undervisningskvaliteten (Hattie, 2009; Helmke, 2013; Meyer, 2005). Det er derfor vigtigt, at undervisernes didaktiske repertoire rummer en vifte af strategier for forskellige indfaldsvinkler til og perspektiver på det indhold, der skal tilegnes. Spørgsmålet er, om bidragene fra DUT bidrager til et varieret metoderepertoire?

\section{Analyseresultater}

Figur 4 viser, hvorledes de bidrag, som har været bragt i DUT i perioden 2006-2013, og som beskæftiger sig med didaktiske temaer på niveauet for strukturanalyse, fordeler sig tematisk.

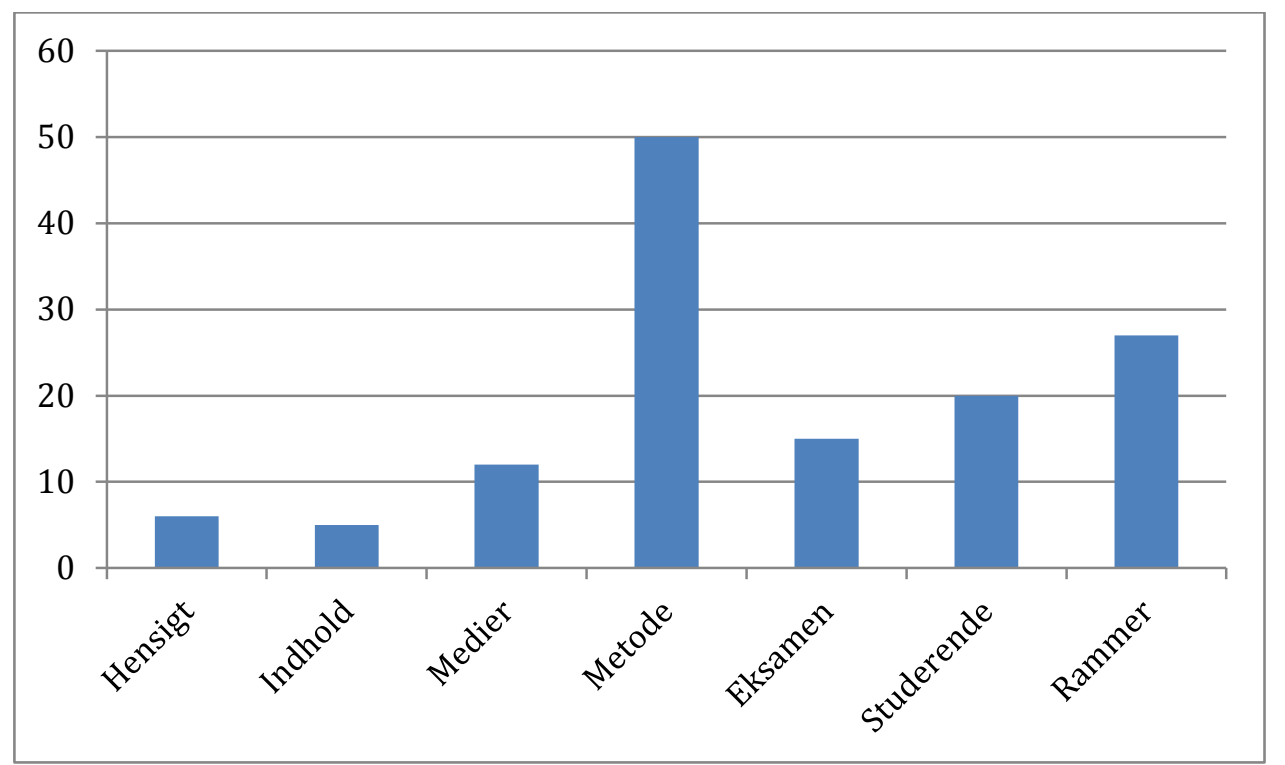

Figur 4. Tematisk fordeling af antallet af didaktiske bidrag på niveauet for strukturanalyse $(n=89)$. 
Figuren viser tydeligt, at metoderelaterede bidrag er langt den største enkeltkategori. Særligt markant er det, at undervisningens hensigt og indholdsudvælgelse kun adresseres i henholdsvis 6 og 5 af de i alt 89 artikler, som beskæftiger sig med didaktik på niveauet for strukturanalyse. Ligeledes er det interessant, at spørgsmålet om, hvem de studerende er som lærende, kun adresseres af omkring en fjerdedel af bidragene.

Ser vi nærmere på, hvilke metodiske grundformer de 50 metoderelaterede bidrag beskæftiger sig med, viser det sig, at de altovervejende har fokus på den studerendes omgang med undervisningens indhold, enten individuelt eller i grupper (Dupont, 2012), eller på undervisningens socialdimension, blandt andet dialogiske undervisningsformer (Dalsgaard, 2011; Hovgaard, 2011). Kun 2 bidrag beskæftiger sig direkte med frontalundervisningen og dennes didaktiske potentialer (Gjerris, 2006; Thøis Madsen, 2010).

Figur 5 viser, hvordan antallet af bidrag fordeler sig på de 3 metodiske grundformer.

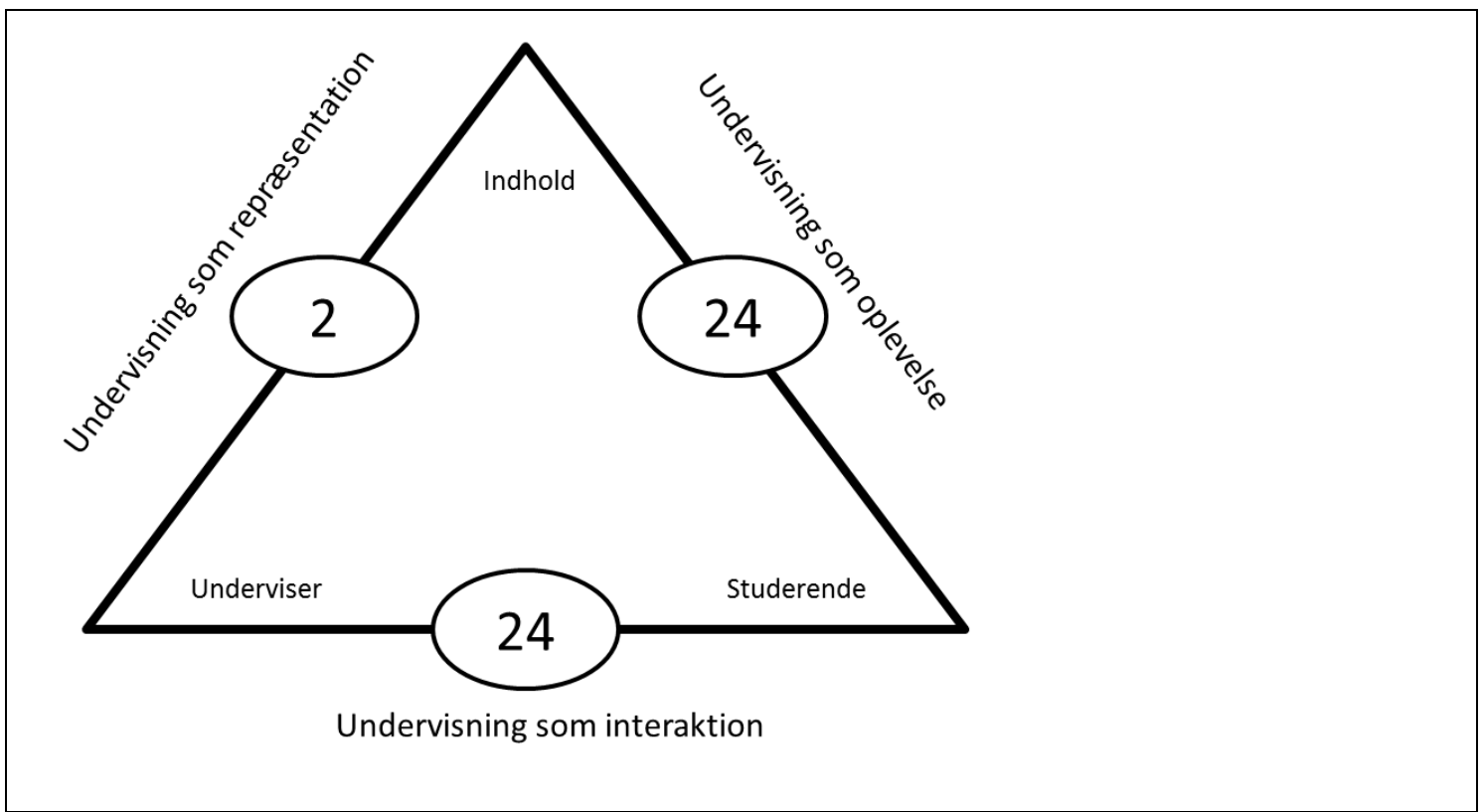

Figur 5. Antal metodeorienterede bidrag, sådan som de fordeler sig på de tre metodiske grundformer $(n=50)$.

I alt 26 bidrag ud af de i alt 115 falder i kategorien 'faktoranalyse'. Der er her tale om bidrag, som spørger til og reflekterer over den undervisningsforståelse, der ligger til grund for iagttagelse af et givet universitetsdidaktisk genstandsfelt. Som eksempel kan nævnes Leth Andersen (2010), der rejser spørgsmålet om, hvorvidt et stigende fokus på 'constructive alignment' fører til generalisering og forsimpling af undervisningens mål og indhold.

Lidt over tre fjerdedel af tidsskriftets artikler (89 ud af 115) adresserer altså universitetsdidaktikken på det refleksionsniveau, som inden for den læreteoretiske didaktik 
beskrives som strukturanalyse, mens diskussioner af grundlaget for de didaktikske analyser tildeles væsentlig mindre opmærksomhed.

\section{Didaktik som metodik}

Som det fremgår af det foregående afsnit, udgør metoderefleksioner langt den hyppigst forekommende enkeltkategori i artiklerne i DUT.

Et nærliggende spørgsmål er, om den stærke metodeorientering er et særligt træk ved DUT, eller om vi også ser det i andre, tilsvarende tidsskrifter. Efterfølgende analyser af det norske universitetspædagogiske tidsskrift Uniped, det australske Higher Education Research and Development (HERD) samt det fagdidaktiske tidsskrift Journal of Geography in Higher Education (GHE) viser et tilsvarende mønster (Keiding \& Qvortrup, 2014a). Dog således, at andelen af metoderelaterede bidrag er markant højere i DUT (se figur 6).

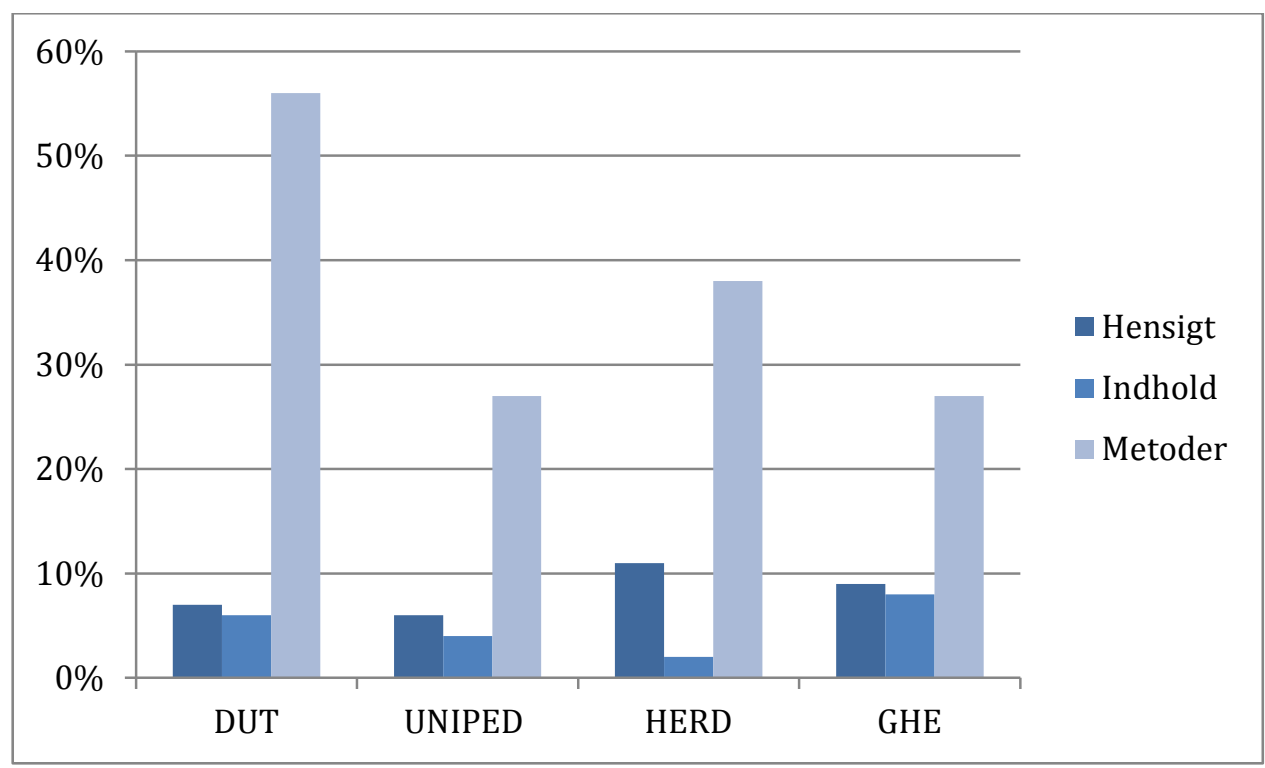

Figur 6. Den procentvise fordeling på udvalgte didaktiske kategorier fra fire universitetspædagogiske tidsskrifter. I alt 318 artikler. På baggrund af Keiding og Qvortrup (2014a).

Metodeorienteringen betyder naturligvis ikke, at der ikke i praksis træffes didaktisk valg om mål og indhold eller, at der ikke findes dansk forskning inden for disse emner. Pointen er, at bidragene fra DUT kun i meget begrænset omfang tilbyder refleksioner over disse temaer. Analysen siger således hverken noget om den danske universitetspædagogiske forskning som helhed, om det omfattende universitetspædagogiske udviklingsarbejde, der foregår på universiteterne, eller om den samlede didaktiske praksis i de undervisningsforløb, der beskrives i artiklerne. Når det alligevel er relevant at interessere sig for, hvilke didaktiske temaer, der fylder $\mathrm{i}$ DUT, hænger det sammen med tidsskriftets ambition om at formidle "forskning, undersøgelser, praksis og debat om universitetsundervisning, -pædagogik og studie- 
kvalitet." ${ }^{1}$ I den forstand er tidsskriftet i vores forståelse med til, men selvfølgelig langt fra ene om, at tegne den universitetspædagogiske forskning i Danmark og er derfor et bidrag til den løbende produktion af forskningsbaseret viden om universitetsundervisning.

Den manglende opmærksomhed på undervisningens mål og disse måls samspil med øvrige kategorier synes problematisk ud fra den betragtning, at det er empirisk velunderbygget, at forskellige metoder har forskellige didaktiske potentialer. Metodevalget må derfor hele tiden reflekteres ift. det mål, som man har med en given undervisningssituation. Spørgsmålet om, hvad "god undervisning" er, kan altså kun besvares, hvis det reflekteres op mod undervisningens hensigt og læringsmål (Biggs \& Tang, 2011; Eikenbusch \& Heymann, 2011; Meyer, 2005). Kun meget få bidrag diskuterer det valgte metodefokus i forhold til andre didaktiske kategorier ( $\mathrm{fx}$ Thorp Hansen, 2011).

Hvis undervisere er interesserede i, hvordan læringsmål kan generes og beskrives, er der inspiration at hente dels i den læringsmålorienterede didaktik (Keiding, 2013b; Möller, 1973), dels i Biggs \& Tang (2011). En markant forskel mellem den læringsmålorienterede didaktik og Biggs \& Tang er, at den læringsmålorienterede didaktik ikke blot beskriver, hvordan mål kan formuleres, men også beskriver processer for produktion af læringsmål. Handler spørgsmålet ikke om den praktiske formulering af læringsmål men om mere grundlæggende spørgsmål såsom, hvilke vidensformer og kompetencer, der er vigtige i videregående uddannelse, finder vi eksempelvis aktuelle bud i Barnett \& Coate (2005), som taler om uddannelse som "knowing, acting, and being" og hos Bengtsen (2014) som taler om "dannelse i overflod", hvormed han peger på den uendelighed af muligheder for læring, den studerende løbende står overfor. Samt i Keiding \& Qvortrup (2015), som peger på, at uddannelse må orientere sig mod tre læringsintentioner: Tilegnelse af værdifuld viden, håndtering af ikke-viden samt nytænkning (innovation).

Hvad angår almendidaktiske refleksioner over indholdsvalg påpegede Ramsden allerede i 1990'erne, at almenpædagogiske bøger om undervisning på universitetet sjældent beskæftiger sig med undervisningens indhold:

"I stedet fokuserer de på metoder til undervisning og bedømmelse af de studerende [...] snarere end på det faglige stof, som det var meningen, at disse metoder skulle hjælpe de studerende med at lære. Naturligvis kan man ikke føre en meningsfuld diskussion om undervisningsstrategier uden referencer til indholdet: Vi underviser altid de studerende i noget." (Ramsden, 1992:152).

\footnotetext{
${ }^{1}$ http://www.dun-net.dk/tidsskrift/om-dut/
} 
Heller ikke Biggs \& Tang (2011), som citeres i knapt 1/5 af de her analyserede artikler, og som også internationalt er blandt de mest citerede forfattere inden for det universitetspædagogiske felt (Tight, 2008b), beskæftiger sig med undervisningens indholdsvalg.

Et blik på et lille udvalg af nyere bøger inden for dansk universitetspædagogik bekræfter denne tendens. Refleksioner over indholdsvalg adresseres således kun på et meget overordnet niveau i Rienecker m.fl. (2013). Stray Jørgensen (2013:153) påpeger således, at det som underviser er "svært at begrænse sig i udvalget, for der er så meget der er fagligt og emnemæssigt relevant. En måde at imødegå den udfordring på er at lade lektionens pointer og aktiviteter styre stofudvalget", mens Mørcke og Rump (2013:96) med reference til Klafki, anfører, at undervisningens indhold bør afspejle "tidstypiske nøgleproblemer", uden at der i øvrigt knyttes an til Klafkis analytiske kategorier for indholdsvalg, som er beskrevet i Klafki (2000). Vi genfinder Klafkis kriterier for indholdsvalg i Ulriksen (2014), hvor der lægges særlig vægt på indholdets eksemplariske værdi.

Ser man nærmere på metodekategorien, ser man, at bidragsyderne i høj grad er optagede af at udvikle og afprøve undervisningsformer, som på forskellige måder sigter mod at bringe de studerede ud af, hvad Kerschensteiner (1971) betegner som den "receptive rolle", og over mod undervisningsformer, hvor den studerende har en "handlende omgang" med indholdet.

Det stærke fokus på handlings- og dialogorienterede undervisningsformer kobles af flere forskere sammen med, at sociale og/eller konstruktivistiske læringsteorier i vid udstrækning har erstattet didaktikken som analytisk grundlag for didaktiske valg (Qvortrup \& Keiding, 2015; Richardson, 2003; Terhart, 2003).

En anden interessant iagttagelse er, at der - til trods for et stærkt fokus på studenterinvolverende undervisningsformer - kun er 20 ud af 89 bidrag, som direkte adresserer de studerende som deltagere og lærende (figur 4). Der er med andre ord på den ene side et stærkt fokus på, at de studerende skal være aktive deltagere i undervisningen, og på den anden side en ret beskeden interesse for de studerendes perspektiv.

Vender vi blikket mod det australske Higher Education Research and Development, ser vi, at omkring 40\% af bidragene adresserer studenterperspektivet (Keiding \& Qvortrup, 2014a). Også Ashwin (2012) tilbyder en række interessante analyser af struktur og handlen i undervisning, som, udover at tilbyde analytiske begreber til analyse af undervisning og studerendes læring, advokerer for vigtigheden af, at vi i stigende grad også forskningsmæssigt interesserer os for det gensidige og dynamiske samspil mellem undervisningen og de studerendes aktive handlen. 
Vores analyse viser endvidere, at refleksioner over undervisningens værdier og normer kun spiller en mindre rolle i bidragene. Konsekvensen er, at DUT kun i meget begrænset omfang kan tilbyde sig som refleksionspartner i forhold til at reflektere det didaktiske grundlag eller pege på andre didaktiske eller værdimæssige udgangspunkter for didaktiske valg. Dette synes at afspejle en international tendens. Således konkluderer Tight (2004) på baggrund af sine omfattende metaanalyser, at forskere inden for videregående uddannelse tilsyneladende ikke finder det relevant at engagere sig i teoretiske diskussioner. Udover at tage fat på sådanne diskussioner inden for den danske universitetspædagogik, vil det være oplagt at vende blikket mod nogle af de få nyere bidrag, der trods alt er på området, eksempelvis Barnett \& Coate (2005) og Biesta (2012). Et andet alternativ finder vi i den tyske didaktik, som også vil give mulighed for at beskæftige sig med nye sider af universitetsundervisningen, fordi denne i højere grad beskæftiger sig med temaer som undervisningens indhold, dannelse og lærerprofessionalitet (Gundem \& Hopmann, 1998; Helmke, 2013).

\section{Konklusion og perspektivering}

Artiklens kategorisering af de didaktiske bidrag til DUT i perioden 2006-2013 viser tydeligt, at bidragene altovervejende er optaget af metodespørgsmål, samt at de, inden for denne kategori, stort set udelukkende beskæftiger sig med handlingsorienterede og/eller dialogiske undervisningsformer. Didaktik sidestilles med andre ord $\mathrm{i}$ vid udstrækning med metodik.

Konsekvensen er, at DUT kun i begrænset omfang kan bidrage til at kvalificere undervisernes refleksioner i relation til de øvrige didaktiske kategorier, som dog til en hver tid er i spil i den praktiske didaktik.

Man kan diskutere, om dette er et problem. Men hvis man tilslutter sig Tight's (2008a) udgangspunkt om, at formålet med universitetspædagogisk forskning er at bidrage til kontinuerlig faglig udvikling af de, som beskæftiger sig med universitetsundervisning, vil det efter vores opfattelse være ønskværdigt, at et tidsskrift som tilstræber at bidrage til etablering af en bred, fælles offentlighed for universitetspædagogiske problemstillinger (Jensen, 2006) i højere grad beskæftiger sig med didaktikken i al dens mangfoldighed, både empirisk og teoretisk.

Tina Bering Keiding forsker i universitetsdidaktik. Teoretisk og analytisk treekker hun på systemteori, didaktisk teori, curriculumforskning samt empirisk uddannelsesvidenskab. De aktuelle forskningsinteresser knytter sig til universitetsuddannelsernes loereplaner og undervisningskvalitet med fokus på målbeskrivelser, indholdsvalg og metoder, primoert projektorganiseret undervisning.

Ane Qvortrup forsker i undervisning og undervisningskvalitet inden for isor videregående uddannelser. Hendes teoretiske ramme er systemteoretisk, og analytisk trokker hun på loeringsteori, didaktiske teorier og empirisk uddannelsesvidenskab. De aktuelle forskningsinteresser knytter sig dels til undervisningens loeringsbegreb, dels til loeringsteknologier i didaktisk perspektiv. 


\section{Litteratur}

Ashwin, P. (2012). Analysing Teaching-Learning Interactions in Higher Education. London: Continuum

Barnett, R. \& Coate, K. (2005). Engaging the Curriculum in Higher Education. Maidenhead, UK: Open University Press, McGraw-Hill Education.

Bengtsen, S. E. S. (2014). Dannelse i overflod - om universitetspædagogikkens luksusproblem. In L. Tanggaard, T. A. Rømer, \& S. Brinkmann (red.). Uren Pædagogik II. Aarhus: Klim.

Biesta, G. (2012). Giving teaching back to education: Responding to the disappearance of the teacher. Phenomenology \& Practice, 6(2), s. 35-49.

Biggs, J. \& Tang, C. (2011). Teaching for Quality Learning at University: What the Student Does (4. ed.). Berkshire: Open University Press.

Broström, S. \& Hansen, M. (2006). Pædagogik: didaktik, læring og dannelse i daginstitution og skole. København: Frydenlund.

Dahl, B. (2010). Kompetencer i matematik ved overgangen mellem det almene gymnasium og universitetet: En SOLO-analyse af progression og vidensformer i læreplaner og kursusbeskrivelser. Dansk Universitetspædagogisk Tidsskrift, 5(9), s. 24-29.

Dalsgaard, C. (2011). Personlige læringsmiljøer: Universitetsuddannelse på internettet. Dansk Universitetspædagogisk Tidsskrift, 6(11), s. 9-13.

Dupont, S. (2012). Nyudvikling af projektarbejdsformen på RUC : beskrivelse og analyse af et eksperiment: "Antologieksperimentet". Dansk Universitetspædagogisk Tidsskrift 712 ), s. 23-35.

Eikenbusch, G. \& Heymann, H. W. (2011). Hvad ved vi om god undervisning? In A. Helmke, C. Walter, E.-M. Lankes, H. Ditton, G. Eikenbusch, M. Pfiffner, H. Meyer, M. Trautmann, B. Wischer, \& H. W. Heymann (red.): Hvad ved vi om god undervisning (side 37-40). Frederikshavn: Dafolo.

Feldt, J. E. \& Dohn, N. B. (red.) (2011). Universitetsundervisning i det 21. århundrede. Odense: Syddansk Universitetsforlag.

Fry, H., Ketteridge, S. \& Marshall, S. (red.) (1999). A Handbook for Teaching and Learning in Higher Education: Enhancing Academic Practice. Oxon: Routledge.

Gjerris, M. (2006). Breakfast at Milliways - The didactic challenges of bioethics. Dansk Universitetspædagogisk Tidsskrift 1(2), s. 45-52.

Grønbæk, N. \& Hedegaard Møller, C. (2013). En problematisering af samspillet mellem centrale pædagogiske principper på arkitektuddannelsen. Dansk Universitetspædagogisk Tidsskrift 8(15), s. 74-84.

Hanson, J. M. \& Sinclair, K. E. (2008). Social constructivist teaching methods in Australian universities - reported uptake and perceived learning effects: a survey of lecturers. Higher Education Research \& Development, 273), s. 169186. Hattie, J. (2009). Visible Learning. A Synthesis of over 800 Meta-analyses Related to Achievement. London: Routledge.

Heimann, P. (1976). Didaktik als Unterrichtswissenschaft. Stuttgart: Klett.

Helmke, A. (2013). Undervisningskvalitet og lærerprofessionalitet-diagnostisering, evaluering og udvikling af undervisning. Frederikshavn: Dafolo.

Hopmann, S. T. (2007). Restrained teaching: the common core of Didaktik. European Educational Research Journal, 6(2), s. 109-124. 
Hovgaard, M. (2011). Stemmekort - et didaktisk værktøj til deltagerinvolvering, feedback og faglig dialog. Dansk Universitetspædagogisk Tidsskrift, 6(11), s. 3443.

Jensen, T. (2006). Dansk Universitetspædagogisk Tidsskrift - derfor! Dansk Universitetspædagogisk Tidsskrift, 1(1), s. 1-3.

Juel, H. (2010). The individual art of speaking well - teaching it by means of group and project work. Dansk Universitetspædagogisk Tidsskrift, 5(8), s. 23-28.

Keiding, T. B. (2013a). Læreteoretisk didaktik. In A. Qvortrup \& M. Wiberg (red.), Læringsteori og didaktik. København: Hans Reitzels Forlag.

Keiding, T. B. (2013b). Læringsmålorienteret didaktik. In A. Qvortrup \& M. Wiberg (red..), Læringsteori og didaktik. København: Hans Reitzels Forlag.

Keiding, T. B. \& Hansen, J. D. (2012). Undervisningens indhold universitetsdidaktikkens stedbarn, Dansk Universitetspædagogisk Tidsskrift, 7(13), s. 105-119.

Keiding, T. B. \& Qvortrup, A. (2014a). The Didactics of Higher Education Didactics. Paper presented at the ECER 2014. The Past, Present and Future of Educational Research in Europe, Porto.

Keiding, T. B. \& Qvortrup, A. (2014b). Systemteori og didaktik. København: Hans Reitzels Forlag.

Keiding, T.B. \& Qvortrup, A. (2015). Undervisning for Læring. Frederikshavn: Dafolo (Manuskript)

Klafki, W. (2000). Didaktik analysis as the core of Preparation of Instruction. In I. Westbury, S. T. Hopmann \& K. Riquarts (red.), Teaching as Reflective Practice. Ther German Didaktik Tradition. London: Lawrence Erlbaum.

Künzli, R. (1998). The common frame and the places of Didaktik. In B. B. Gundem \& S. T. Hopmann (red.) Didaktik and/or Curriculum. New York: Peter Lang.

Leth Andersen, H. (2010). "Constructive alignment" og risikoen for en forsimplende universitetspædagogik. Dansk Universitetspædagogisk Tidsskrift, 5(9), s. 30-35.

Luhmann, N. (2006). Samfundets uddannelsessystem. København: Hans Reitzels Forlag.

Meyer, H. (2005). Hvad er god undervisning. København: Gyldendal.

Murray, R. (red..). (2008). The Scholaship of Teaching and Learning in Higher Education. Maidenhead: Open University Press \& McGraw-Hill.

Möller, C. (1973). Technik der Lernplanung. Weinheim: Beltz.

Mørcke, A. M. M. \& Rump, C. (2013). Universitetspædagogiske modeller og principper. I L. Rienecker, P. Stray Jørgensen, J. Dolin, \& G. H. Ingerslev (red.), Universitetspædagogik. Frederiksberg: Samfundslitteratur

Qvortrup, A. \& Keiding, T. B. (2015). The mistake to mistake learning theory with didactics. In G. Christensen, M. Hansbøl, A. Qvortrup, \& M. Wiberg (red. On the Definition of Learning. Odense: Syddansk Universitetsforlag.

Ramsden, P. (1992). Learning to Teach in Higher Education. London: Routledge.

Richardson, V. (2003). Constructivist pedagogy. Teachers College Record, 105(9), s. 1626-1640.

Rienecker, L., Stray Jørgensen, P.. Dolin, J. \& Ingerslev, G. H. (red.) (2013). Universitetspædagogik. Frederiksberg: Samfundslitteratur

Stentoft, D. \& Østergaard, L. D. (2013). Artikelskrivning som eksamensform. Dansk Universitetspædagogisk Tidsskrift 8(15), s. 47-59. 
Stray Jørgensen, P. (2013): Lektionsplanlægning. In L. Rienecker, P. Stray Jørgensen, J. Dolin \& G. H. Ingerslev (red.), Universitetspædagogik. Frederiksberg: Samfundslitteratur

Terhart, E. (2003). Constructivism and teaching: A new paradigm in general didactics? Journal of Curriculum Studies, 35(1), s. 25-44.

Thomsen, J. P. (2007). Senmodernitetens universitetsstuderende? Dansk Universitetspædagogisk Tidsskrif, 2(4), s. 4-11.

Thorp Hansen, C. (2011). Udvikling af et kursus i konceptsyntese for forskellige ingeniørstuderende. Dansk Universitetspædagogisk Tidsskrift, 6(11), s. 32-38.

Thøis Madsen, P. (2010). Hvordan skal man undervise ikke-økonomer i økonomi? Dansk Universitetspædagogisk Tidsskrift 5(8), s. 35-39.

Tight, M. (2004). Research into higher education: an a-theoretical community of practice? Higher Education Research \& Development, 23(4), s. 395-411.

Tight, M. (2007). Bridging the Divide: A comparative analysis of articles in higher education journals published inside and outside North America. Higher Education, 53(2), s. 235-253.

Tight, M. (2008a). What's the point of it all? Researching and writing higher education. Uniped, 31(4), s. 61-69.

Tight, M. (2008b). Higher education research as tribe, territory and/or community: a co-citation analysis. Higher Education, 55(5), s. 593-605.

Trigwell, K., Martin, E., Benjamin, J. \& Prosser, M. (2000). Scholarship of teaching: A model. Higher Education Research \& Development, 19(2), s. 155-168.

Ulriksen, L. (2014). God undervisning på de videregående uddannelser. En forskningsbaseret brugsbog. Frederiksberg: Frydenlund.

Westbury, I., Hopmann, S. \& Riquarts, K. (red.) (2000). Teaching as a Reflective Practice: the German Didaktik Tradition. Mahwah, N.J.: L. Erlbaum Associates. 